UDC 821.163.41-14.09 Tešić M.

https://doi.org/10.18485/ms_zmskij.2020.68.1.16

Др Драган Л. Хамовић

\title{
РЕКАНОНИЗАЦИЈА СТИХА И ОБЛИКА И ЮЕН СМИСАО У ПОЕЗИЈИ МИЛОСАВА ТЕШИЋА
}

\begin{abstract}
У раду настојимо да пружимо целовитији поглед на досадашње песничко дело Милосава Тешића, почев од поетичких оправдања његовог доследног опредељења за метричко начело организације стиха, док метре подвргава опиту и иновацијама, као и у сталним строфичким облицима. У светлу развијене поетичке и културне самосвести, разматрамо развој Тешићевог опуса, обележен тематским померањима и продубљењима, као и књигама пројектима на подстицаје из матичне културе и језика, те песмама дугог обима, по којима се издваја међу песничким савременицима.

Кључне речи: Милосав Тешић, савремена српска поезија, српски стих, наслеђе симболизма, културна самосвест.
\end{abstract}

Песма Куйиново, насловна песма прве збирке песама Милосава Тешића (1986), изведена у седам осмерачких дистиха, звучи блиско у томе типичном размеру усмене лирике, али зачуђује и подстиче семантичка отвореност што се пружа у више асоцијативних смерова, из нејасног, узбуњеног стања песничке свести. Сву раздешеност произведених значења и сазначења сједињује облик песме, који је, по речима Бранка Миљковића, једини коначан. „Растрганост форме чини немуштим противуречности поетског садржаја“ (Миљковић 2018: 36), писао је предводник групе неосимболиста, док се одговарајућом формом „сједињују најразличитије алузије, утисци, несувисли појмови и значења у једну неразлучиву целину“ (115), а да „тежња ка строгој организацији песничког градива одузима песнику слободу да буде произвољан и неодговоран, али му даје пуну слободу да сам одабере облик организовања песме“ (116).

У истом смеру, Милосав Тешић сведочи своје искуство обликовања песме. „Не угони се језик тек тако у метричке обрасце“, исказаће једном нарочитом приликом, јер „потребно је носити терет и личног и колективног расула; нужно је, следећи метричке импулсе, уредити тај микрохаос, уврстити га и извести на сунце“ (ТЕшић 2004: 173). Као што можемо видети, унутар чврстих формалних оквира збива се драматична неснађеност и фраг- 
ментираност песничког субјекта, одлика која га изнутра, суштински лоцира у наше доба и међу своје савременике. Подршку таквом приступу, у контексту укупне модерне ситуације, одавно је дао Хуго Фридрих: „Одувек су песници знали да се патња разрешава у песми. [...] Али тек у 19. веку, када је патња са циљем прешла у патњу без циља, у пустош и на крају у нихилизам, форме су се понудиле као спас, иако оне, као нешто затворено и мирујуће, стоје насупрот немирним садржајима“ (Фридрих 2003: 39-40).

Форма као оруђе спаса, насупрот безобличном метежу егзистенцијалних реалија, задобија у тумачењу Сергеја Аверинцева сакралну подлогу: ,'Форма' се контрапунктно спори са 'садржином' [...] јер 'садржај' - то је сваки пут људски живот, а 'форма' - подсећање на 'све', на 'универзум', на 'Божји свет'“ (АвеРинцев 2010: 90). „Класична форма“, по Аверинцеву, „даје своју меру свеопштег, његов контекст, - и тиме изводи из ћорсокакака личног“. На трагу нове критике, Јован Христић - иначе, као песник остао доследно изван везаног стиха - указује још у доба пуне превласти поставангардне доктрине, да је метар „основни чинилац који нам помаже да се и сами структурирамо“ (Христић 1957: 72). Ово су неки „метаметрички“ разлози за окретање строгој форми - а метар је искључиви Тешићев избор, опција с почетка прећутна, а од средине деведесетих, према признању аутора, све освешћенија и постојанија.

Свакако да је уочљиво место Тешић најпре изборио првом у низу својих дужих песама, под насловом Rosa canina. Био је то захват дугог даха, у децимама и лирском десетерцу, који је, по више елемената, опомињао на лабудову песму нашег романтизма, Santa Maria della salute Лазара Костића, изворника модерних песничких нараштаја. Али, Rosa canina само подсећа на Костићеву завештајну песму, Тешић не преузима готове формалне и метричке елементе славног претходника, него првенствено сигнализује да је Костићева песма у подтексту Тешићеве као остварење узорито, као еталон песничке традиције коју дијалошки призива. И за песму Rosa canina важи претходно запажање да нелинеарни, дисконтинуирани низ различних и чудних слика и значењских склопова постаје обједињен формом, једино коначном. Песма тиме поприма повишен набој, скоро неприсутан у камерним атмосферама песника новијих времена, док језичка имагинација, заснована на вишеслојности коришћених лексичких елемената, постаје чинилац од прворазредног значаја.

Другим речима, песник полази од тога да је песма пре свега уметност речи, која креира засебне и самодовољне светове, те да је она и уметност $c \bar{u} u x a$, односно вештина уређивања говорног низа према извесним правилима. А стих није само технички оквир што некоме помаже а неког оптерећује у изразу, наслеђено помагало или непотребност. Стих улази у кључне творевине које нам је усмена култура уопште оставила у наслеђе. Основна улога стиха је „проистекла из његове велике мнемотехничке моћи, па се с много ваљаних разлога може поредити с каснијом улогом писма“ (Петковић 2006: 18). Не може се пребрисати, поред свега догођеног, да се од раздобља 
усмене културе у стиху „чувају само она обавештења која је вредело сачувати (ради опстанка људске заједнице и њене културе), а остала ишчезавају заједно са тренутним текстом који их носи“"(Исто). Стих је не само допунски облик уређења текста, него и медијум културног памћења. Све ово свакако има на уму Милосав Тешић у подухвату што захвата у дијахронију памћења српског језика и враћа се изломљеном лику епохалне стварности.

Недавно је песник, не би ли помогао тумачима, подробно описао своје метричке погледе, који су, разуме се, подложни провери, али је мало за то и заинтересованих и спремних:

Ти метрички знатно строжи стихови у односу на своје класичне узоре у бити су, шире гледано, један од знакова моје привржености потврђеним националним културним и духовним вредностима, које се много боље чувају добро нађеном новином него сталним подражавањем, али су и вид опирања одбацивању и ниподаштавању нечег што спада, естетички гледано, међу највредније домете у развоју модерног српског песништва, што му даје изразиту особеност, то јест оригинално, јединствено обележје (Тешић 2016а: 581-582).

У први план, као што видимо, песник истиче верност идеји креативних континуитета, данас увелико скрајнутој, уз његов испитивачки однос и уношење метричких иновација, као и отвореност према баштињеним вредностима.

Не почиње ништа с нама, нити завршава. Ништа друго Тешић овде не сведочи него једно од кључних становишта Елиотове поетике традиције, која је била потакла и усмерила најпродуктивније и најоствареније напоре прошловековне модерности, не само у поезији: „Постоји нешто изван уметника чему он дугује лојалност, оданост, чему мора да се преда и жртвује да би стекао и задобио свој јединствен положај. Заједничко наслеђе и заједничка побуда уједињују уметнике свесно или несвесно“ (Елиот 2017: 91). Мало је уметника са тако израженим смислом за традицију као за област неисцрпивих изворишта нових импулса и препознавања.

Леон Којен, најпозванији савремени тумач Тешићевог и српског стиха уопште, дао је следећи интерпретативни оквир за приступ потиснутој теми: „У историји српског песништва, као и у историји европског песништва уопште, напуштање везаног и прихватање слободног стиха почетком двадесетог века сигурно је била једна од далекосежнијих промена у домену изражајних средстава““ (Колен 2012: 129). Којен даље истиче да је ова промена утицала на идеју о изједначавању слободног стиха са модерном поезијом, али и то да су песници друге половине двадесетог века углавном напуштали силабичко-тонски метар класичног српског стиха, пре посежући за римом и строфичком облицима као изражајним средствима из традицијске залихе. Књижевни преврат у нас, покренут авангардом после Првог светског рата, писао је Новица Петковић, укључује програмску деканонизацију, „која се 
није уводила [...] само у ритам него уопште у песнички текст, све до његове композиције и жанра“" (ПЕтковић 2007: 33), што пак није довело до њиховог укидања. У домену стиха, деканонизација је прво значила напуштање статике и динамизацију, као и могућност слободног избора погодби. Ипак, већина песника, наставља Петковић, по инерцији доводи свој стих, ритмички гледано, у раван са прозом, тј. напушта све погодбе везаног стиха. Тај процес је био навео Аверинцева на коментар да ,ако верлибром називамо извесне песме старијих песника [...] онда би за данашњу продукцију требало изабрати неки други назив““ (89).

Милосав Тешић при томе делује као против струје, широке и незадрживе, али у својој реканонизацијској замисли почетком последње деценије прошлог века није био сам, обрео се у најбиранијем песничком друштву. Почетком деведесетих, Иван В. Лалић објављује већ чувену књигу Писмо (1992), којом се враћа везаном стиху, као на почецима свога песничког рада, средином педесетих. После књига Кључ од куће (1991) и Благ̄o Божије (1993), Тешић објављује дводелну књигу Прелести севера, Круг̄ рачански, Дунавом (1996), где нарочито привлаче пажњу ронда испевана у јампском једанаестерцу, уз друге строфичке форме увезене из дубоке романске лирске традиције (в. Стипчевић 1997: 17). Такав увоз из европских залиха омогућава песнику да савладава отпор језичког материјала у захтевним формама које је српска поезија или слабо или никако познавала те да евокује стилска сазвучја позног барока, у чије се панонско окриље сели поворка учених рачанских монаха, лирских јунака што дају гласа у поменутим рондима. Песме Лалићеве и Тешићеве у јампском једанаестерцу Којен је објавио као историјски догађај и потврду виталности класичних метара српске поезије, а нагласак његове пажње био је на разматрању њихових метричких стилова, тј. новина унутар норме овога силабички-тонског класичног стиха: „Али, док је Лалић ишао путем смишљеног слабљења метричких стега да би свој једанаестерац ослободио конвенционалних ритмичких асоцијација и дао му потпуно индивидуалан печат, Тешић као да је свесно пошао обрнутим путем, бирајући метричку строгост тамо где се Лалић опредељивао за метричку флексибилност“ (КоЈеН 2012: 155).

Кад метричка строгост однесе превагу над могућностима разложног одступања, када се постави задатак високо и безусловно, онда је реч не само о ауторском изазову, него и опиту што испитује уврежена становишта и предрасуде, а надасве непотврђене догмате поставангардне поезије. На углавном напуштеном делатном пољу српског стиха, с ретким вредним изузецима, Милосав Тешић се, почев од спева Седмица (1997) па надаље, поред ширења и дубљења тематског видокруга, посвећује богаћењу активног изражајног репертоара посткласичних српских метара (нпр. дактило-трохејски десетерац и петнаестерац, јампски десетерац) да би, рецимо, увођењем амфибрашког дванаестерца остварио значајан искорак унутар српске версификације (КоЈен 2012: 174). На могућне приговоре: 1) где је у свему томе значење, или 2) какво је то мучење и извештаченост језика и 3) шта 
ћемо са слободом и спонтаношћу, теоријска мисао дала је темељан одговор указујући на неразлучиву спрегу „звук-значење“ и на увид да се „версификација никада не може у целини извести из постојећег језика“ (Јакобсон), него да је увек посреди веће или мање „насиље над језиком“ (КоЈен 1998: 77). И у Тешићевом случају, чији напор да изнађе решења до којих се не долази олако, укидајући себи слободу - како је писао Миљковић - да буде произвољан и неодговоран, најостваренији су они напори изведени „у тесном склопу метрике и бола“, у изласку из „ћорсокака личног“, с ослонцем на дату „меру свеопштег“ и мрежу вишестепене хијерархијске организације. Јер стих је „систем вредности“, што му је додатна препорука у раздобљу невредности и безвредности.

Бирати строга самоограничења у доба укинутих граница, чини редак избор, раван подвигу, уколико се покаже и делатним. Ако пођемо трагом Лакановог одређења писања као „покушаја маскирања трауматичног језгра помоћу поистовећења са симболичним књижевним смислом“, онда бисмо, уз нужне резерве према дометима таквог приступа, упориште за речени подсвесни завет најстрожег „слогомерија“ могли изнаћи у опису из Тешићеве аутофикцијске прозе Са стианищйа брезових дедова (2002). У тој прози песник приповеда о првачкој трауми због муцања и говорне блокаде, као тешком раном јаду на почетку формативног периода:

Застрашен школом (рачуном, шибањем, клечањем на ораховим љускама, школским затвором, где има и вампира), одузео бих се кад би ме учитељ било шта упитао. Нисам могао нормално изговорити ни најпростију реч. Ухвативши ме за руку - а тек сам био првак тромесечић - учитељ ме је, пошто сам, у страху од замуцкивања, отћутао свако његово питање, повео из клупе, извео пред ђаке и дословце рекао: 'Ово је најгори ђак у школи!' Покуља из мене осећање личне ништавности и у слојевитим магленим пластовима обујми огромну булку срама, под чијим сам црвеним цветом тонуо у под и пропадао у подрум (Тешић 2002: $84-85)$.

О међузависности певања и муцања сведочили су песници од респектабилног искуства, па и сам Тешић, нпр. у поеми Благ̄о Божије, када у финалу описа предјесењег предела пита: „Шта ће јабуци муцај песника“. Борислав Радовић, који је написао стих „Слово је цртеж дуге патње изговора“, или: „Говорити је мучно; само је тешко / држати камен у устима“, написао је и лирску параболу о „игли у устима“, древном надметању кинеских песника. Јер песма је, заправо, говор са препрекама. Оно што препреке пређе, достојно је песничке речи. Сагласни поредак песме представља чин превладавања трауме, симболичну победу над њом. Али без притиска задатих оквира, неретко, нема ни речи истиснутих из дубљих степена свести, које, уосталом, више припадају наслеђу него нама самима.

Већ је истакнута мнемотехничка страна стиха, као медијума културне меморије, њених битних, одабраних обавештења. Пошто је почео да обликује 
свој модел песничког света у знаку топонимских подстицаја, Милосав Тешић постепено улази и у друга подручја активираног језичког памћења, призива их и комбинује, засведен изабраним размерима и облицима. Како је Радивоје Микић био приметио, Тешић, „у именима места, читавих крајева или појединих пејзажа, најпре настоји да пронађе подстицај за неку врсту етимолошких игара [...] а потом, постепено, почиње да гради асоцијативно-симболичку основу на коју ће смештати историјске реминисценције [...] или, пак, настоји да сам језик гледа из необичне перспективе - као материјално-предметну сферу““ (Микић 1998: 33-34). Поезија укида дословно приказивање и успоставља посебну сферу, изграђује смисао неразлучив од укупног склопа, отима се свакој парафрази. Тако је и с лирском семантиком Милосава Тешића, аутора наслеђа симболизма, и то симболизма схваћеног у ширем обухвату, тј. као особеног конструктивног тока модерног кретања, заснованог на респекту према језику и истанчаном истраживању његових могућности.

Књига Кључ од куће оличава базични круг далекосежног поетског подухвата, сједињења потиснутих и живих слојева националне предаје. Од ове књиге почиње опит тога обухватног освешћења. Јер стара сеоска кућа, о којој се пева, није у основи дата као опис реалне породичне куће из које потиче, него као модел у сложеној семиотизацији традиционалне културе, углавном пресељене у прошлост. Управо као што објашњава Снежана Самарџија, уважавајући иманентну двосмисленост говора у поетској функцији:

Кућа разграничава своје и туђе, културу од стихије природе, али, посебно стара, патријархална сеоска кућа оличава пуноћу и континуитет живота, спајајући претке и потомке. У Тешићевом циклусу, око куће у којој се живи подигнути су магаза, амбар, вајат, воденица, који се заједно са бунаром, дрвљаником и пчелињаком повезују на два начина. С једне стране, то је аутентична слика сеоског газдинства, наспрам којег је постављена урбана средина, представљена са уочљивом иронијском дистанцом. С друге стране, сви издвојени 'предели' од посебног су значаја за култ предака у српској митологији. Додају ли се томе слике гумна, међе, ливаде, пландишта, појила и воћњака, око куће се шири трећи концентрични круг, као збир табуисаних места у религијском систему, на којима се приносе жртве боговима и мртвима (САмАРџијА 1998: 79).

Кућа је, у Тешићевој лирској пројекцији, слика укупне српске прошлости, веровања и деловања, чији је крајичак и сам проосетио и описао у песмама с мотивима детињства. И при овом тематском градиву Тешић посеже за формалним изазовима, самооптерећењима, као и укрштајем личне уобразиље с древним погледом на изабране, културно кодиране слике. У песми Кућне дуще мирис песник уводи облик ронда и то на подлогу епског десетерца, с наглим опкорачењем ради метапоетичког коментара, уз лирске слике флуидног описа и с благозвучним рефреном: „Залелуја кућне дуще мирис!" Корпус етнолошких представа о кући и у вези с кућом стиче се, баш у песми Kyћa, у симетричном десетерцу с дактилским, римованим заврше- 
цима. Својеврсно „растројство чула“ и сновидовни, ишчашен поглед изобличава наслеђене елементе, од предмета и обреда до бића из предачког пандемонијума: „Тресе се кућа с крова, темеља: / јауче Среда, кука Недеља, / чангрља поноћ дрвен-жлицама.“"Поред осталог, у песми Дивља кућа, кућа се очовечује и уједно озверује, па она, уместо заштите од стихије, постаје стихија сама („Олистала буником крене кућа у шуму“), у четрнаестерачким дистисима (у ствари, удвојеним трохејским седмерцима) с дактилским римама на крају.

Као што ни кућа није само кућа, тако су и њени унутарњи и дворишни елементи „већи од своје величине“. Није Милосав Тешић ни први ни последњи песник што опева наше патријархално старо огњиште, али је, колико знамо, једини у нас што је, у књизи Кљууч од куће, израдио енциклопедијски опсежну а чудесну слику народног света, потакнут имагинативним изворима тога архаичног света, који даље, неосвешћено или полусвесно, носимо у себи - ко мање ко више. А читав тај свет песник увелико призива из непостојања, изнова га окупљајући и повлашћујући у песничком облику.

Триптих тзв. сонета продуженог трајања - а то је Тешићев формални изум од четири катрена са завршним дистихом - песма под насловом Читиајући Данила. Светии Марко, обликује лирску представу у којој се укршта евокација конкретног детињства, не само с мозаичним описом појединости славске свечаности, него и са алузијама на политичко-историјски контекст песниковог одрастања, под идеолошком опресијом што је ништила вредности села и српског народа: „С колијевке братац ми поцупкује гучући, / а кроз

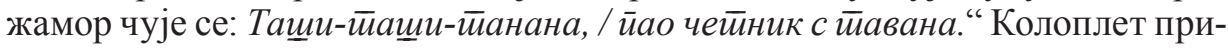
званих слика и гласова у поретку удвојеног седмерца, односно четрнаестерца са дактилским завршецима, с укрштеним римовањем и често ослабљеним римама, интегрише се у томе строго организованом ритмичком склопу.

Збирка Кључ од куће наставља у збирци Куйиново почету топонимску бројаницу, већином у осмерачким дистисима, али звучна асоцијативност назива места уступа место културноисторијским призивима, пре свега у косовско-метохијском лирском низу. У томе ходочашћу контрасно сучељава пуноту негдашњег бивања и пустош актуелног лица наше средишње земље: „Смрачујеш се, дедовино, / а зри јечам, а зри вино“ (Призрен, Гьилане). И у књизи Благ̄o Божије Тешић пресабира и допуњује тематско-формалне токове својих почетних песничких занимања. Поред завичајних и природних призора, место налазе гротескно-веристички засновани описи савременог метежног и испразног живота, урбаног и новокомпоновано сеоског, али насловна песма доноси нови ауторски продор у дужим песмама. А дуже песме чине готово засебан круг Тешићеве поезије, који се наставља и развија у свим његовим књигама до сада.

Смештајући лирски амбијент песме Благ̄o Божије (и она је, као Rosa canina, у симетричном десетерцу и децимама) у меланхоличну раскош михољског лета, и овде песник укршта химнични тон усмерен према природној творевини, сакрализује пределе. Јер, природа је Речник којим Творац 
проговара, симболима што их духовно откривамо, безмало да пропевају у последњим данима лета: „Што не пропоје / Благо Божије, макар покоје / Слово чудесно.“ У овој важној песми за Тешићев опус, почиње да се непосредно уводи перспектива чије се порекло налази у средњовековној поетици, која невидљиве светове сагледава у видљивом свету препуном Благ̄a Божијеz. Јер прави духовни свет, пред људским и песничким очима је као у загонеци, по речима Димитрија Богдановића, „нејасан, али ипак видљив и присутан, наслућен довољно да се са њим може жудети, да се са њим може успоставити жив, активни однос“" (БогдАновић 1991: 66). Управо тако је и овде, у песми Благ̄о Божије.

При убрзаном природном растроју ипак се еманира лепота. Расуло се наговештава још у зениту вегетативног циклуса, док лирски глас зазива спасоносну јавку Логоса да ту лепоту одржи, сачува. Слике из различних нивоа стварности стичу се у строгој форми, згушњавају, вртложе, засветле и затамњују. А божанско присуство у опису песник слути и сведочи, упоредо с исказом мука песничке артикулације, немоћне пред неисказивим збивањем. Као што је, иначе, Створитељ људским умом и речима непојмљив и неописив. Парадокс највише лепоте творевине у часу почетка замирања слика је коју, кроз сакралну „синтезу супротности“, посредује ова Тешићева песма и долази до српсковизантијског становишта изнутра, као припрема за предузећа у која ће се песник управо упустити.

Не само у дужим песмама које у архитектоници Тешићевих књига поседају истурена места, песник се осведочио као извођач замашних пројеката Прелесіи севера, Круг̄ рачански, Дунавом (1996) ${ }^{1}$ и Седмица (1999). Када је Миодраг Павловић писао оглед о саборцу с почетка педесетих, о Васку Попи, отворио је тему могућности надилажења лирске формуле и остварења „епа нашег времена“, истичући да је крупан корак у остварењу великих облика у модерној поезији „циклична организација“ (в. Павловић 1964: 239). Павловић се, као песник, доцније упустио у спевове с ерудитном културном подлогом. Семантички делатан концепт циклизације Тешић свакако показује од књиге Кљьу од куће. Јединице циклуса се уланчавају и прожимају, обликују замишљену макроцелину од лирских саставака обједињених обликом и ритмом, а највише тематским контекстом.

Књигу Прелести севера, Круг̄ рачански, Дунавом, што евокује Велику сеобу, с тежиштем на топосу манастира Раче за који је песник завичајно везан, одиста можемо посматрати као еп у саставцима. У том „епу“ се огледају и препознају два временска плана: давна епоха Патријарха Чарнојевића и актуелна историјска позадина, обележена невољним померањима наших савременика из западних крајева бивше заједничке државе Јужних Словена, али и са југа Старе Србије, одакле је стара сеоба некада кренула. Реч је

${ }^{1}$ Најпре је објављена књига Прелести севера (1995), која ће наредне године бити допуњена тематском збирком Круг̄ рачански, Дунавом. Песник је доцније објавио Круг̄ рачански, Дунавом и засебно (1998). 
одиста о књизи-пројекту, која почива на потанком знању епохе, изведеном и као разнолика и полифона целина и на плану појединачних, велемајсторских песама. Из велике људске групације што напушта своју родну земљу због претње затирања, песник издваја групу, историјских и фиктивних, рачанских монаха, писара и писаца чувене рачанске школе, који своје главе и своју ученост селе у панонске крајеве да тамо очувају православно предање којем су заветовани.

Средином ратних деведесетих, када и настаје Прелест̄ севера, Круг рачански, Дунавом актуелизују се, у страшном лику, сеобе као историјски архетип српског народа, као „наслов наше судбине“, по речима Сретена Марића о роману Милоша Црњанског. Миљковић је, за кратког века, у средиште неостварених песничких планова постављао тежњу за националним симболима као универзалним знацима, на трагу претходника модерниста, зарад еманципације српске културне основе. Тешић, опет, симболизацијом предачке куће наставља у реченом смеру, док је овај давни повесни одељак пресликао не само на актуелну, него и на општељудску ситуацију измештености, а културне напоре означио насупрот процеса претапања у туђем простору. У основи ове сложене песничке целине можемо распознати оно што је Димитрије Богдановић, пишући о средњовековној књижевности, називао библијско-хришћанским историзмом, „вечним презентом“ повесне егзистенције: „Комуникација са прошлошћу је тада непосредна, духовна, у извођењу онога што је опште, а из историје - онога што је надисторијско, метаисторијско“ (БогдАновић 1991: 64). Није посреди, значи, површна актуализација него метаисторијски, духовни поглед на трајање заједнице и појединаца. Све обликовне и тематске одлике дотадашње Тешићеве поезије изналазе своју временску и просторну конкретизацију, било да је тематизован покрет колектива, историјски и културни топоси, или лирски јунаци и њихова хтења и удеси.

Већ у пролошкој дужој песми Пуй Паноније, поред живих душа и преносивог иметка, на север се склања и духовно наслеђе, али и сећања на матични простор и прошли живот које се оставља за собом. Све је у покрету, материјално и нематеријално, па и алфабет и монашка писана течевина: „У

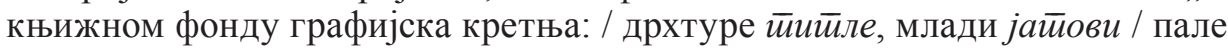

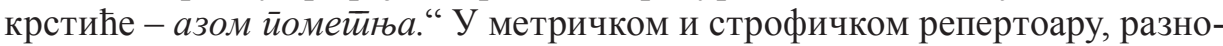
врсном и пробраном према изражајним средствима епохе, посебно се, по ритмичкој гипкости и семантичкој просветљености - како је већ истакнуто - издвајају ронда у јампском једанаестерцу, у необичном сусрету српсковизантијске и западне традиције. У рондима проговарају монаси, лирски јунаци с обичним људским тежњама и бојазнима и унутарњим борбама. А једна од опсесивних тачака њихове борбе јесте носталгија за рачанским пределима. Тако круг рачански кружи без заокружења, као у песми „Чудо у Рачи“: „У петак смеђи / Кипријан сури / с крстом у веђи, / уз Дрину жури. // Вавек се сели / и блудним селом / о камен бели / удара челом.“ Опстанак је привремен и делимичан, расејани народ се гаси на ободима на којима 
оставља највише културне трагове. Трагови живота и стварања, од српске топонимије до храмова и других здања, од ликовних артефаката до писаних дела, доносе двосмерни смисао, утешан и неутешан, о пролазности и непролазном. О условној пролазности и условно непролазном.

Поступак онеобичавања језика, као особени знак Тешићеве поетике, у књизи Прелест̄ севера, Круг̄ рачански, Дунавом, постаје разгранатији но раније, „од фонетског симболизма и творбе оказионализама, преко симболичког укрштања различитих идиома истог, српског језика (књижевног језика са дијалектима, жаргонима, социолектима) и његових различитих изговора - екавског и ијекавског, до укрштања, са истом функцијом, различитих језика - српског, мађарског, латинског“, пише Александар Милановић, а наглашава и то да су елементи фолклорног и архаичног, осим у лексици, присутни и на осталим језичким нивоима (МилАновић 1998: 60). Особити су, за осликавање епохе, црквенословенизми и графија превуковске азбуке, захваћени повременим металирским и метајезичким коментарима, којима се обично исказује Тешићева поетичка самосвест. У новијем раду о Тешићевом песничком језику, Милановић елементе средњовековног „плетенија словес“, раније описане у литератури, препознаје и код Тешића колико и у народној и романтичарској поезији, да би закључио да је песник ,реализовао један модеран концепт доситејевског језика, у којем су у срећној коегзистенцији поетичке и стилске црте и бившег књижевног и бившег и садашњег народног језика, те да се таквом концепцијом поетског језика приближио поезији Петра Петровића Његоша“ (МилАновић 2016: 276).

Поред укрштаја језичких слојева, Тешићева поезија је, укупно узев, упоредива с Његошевом и по једновременој употреби класицистичких, романтичарских и усмених метричких размера и стилских средстава, али не једино по томе. Када чита спев Седмииа Милосава Тешића, поред асоцијације на Четиири канона (1996) Ивана В. Лалића, читалац помишља на спев Луча микрокозма (1845) као на традицијски подстицај или претечу. И Лалићева и Тешићева књига су, у тренутку појаве, прихваћене као крајњи досег сусрета српског песничког модернизма са српским средњим веком, као са скрајнутом баштином. Лалић саображава песнички склоп свога - може се такође условно одредити, „спева“ - формално-тематској структури преузете литургијске врсте, а прожима је тематским градивом из епохалне стварности из које се оглашава. Тешић, с друге стране, задржава освојене песничке облике, најпре рондо у јампском једанаестерцу у првом делу свога циклизованог спева, док у другом делу Седмице модификује неке сакралне строфичке облике, имајући на уму њихове базичне тематске одлике. Уводи и формалну иновацију, која ће у песмама наредне збирке показати своју изврсност: амфибрашки дванаестерац, овде у кратким песмама означеним као псалми.

Остварити у наше доба, макар и дисконтинуирани спев на патетичну космолошку тематику, било је могуће једино ако се грандиозна тема некако приземи, доведе у везу са мукотрпним индивидуалним чином стварања, 
за шта је припремљен терен и у ранијој Тешићевој поезији, најочитије у песми Благ̄о Божије. Песник преузима од далеких претходника, као и од Његоша, основну идеју о свештеном звању поете - те је изражава у скрушенијем ставу и појачаној сукобној динамици чина стварања: „У йесном склойу мейрике и бола, / финоћу бруси регистар од патњи, / а свећом лана мучеништво пламти“" (Среда, VI). Двосмисленост о каквом се стварању овде ради

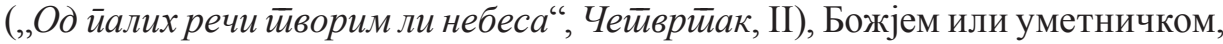
чини окосницу песничког пројекта што прати свештени образац „седмице“. Песнички глас обраћа се из „савечне“" творачке перспективе, лако се помичући по временској оси, од почетка свега до часа певања, часа сведочења о учинку и противречјима стварања. Или је пак реч о идеји стварања што не престаје, ни у великом као ни у малом? Ова питања уносе додатни замајац смисаоној неразрешености спева Седмица.

Један од млађих тумача, Марко Радуловић, у Седмици с правом налази неке од „битних видова обнове средњовековног наслеђа у послератном модернизму: песник као дијак и обнова молитвене духовности, поетика као теодицеја, те природа као хронотоп Божјег присуства“ (РАдуловић 2016: 390). У другом делу спева, након стваралачке седмице, у окриљу каталога призваних богослужбених врста, за којима песник посеже у своме обновитељском опитовању на плану облика, наставља се динамика пропитивања и дивљења Божјем делу, пре свега с искуства земље којој песник припада. Драматика и противности остају, али и непрестана потреба за одбраном суштине дела Врховног Песника. Ванредни су ауторски напори уложени у овладавање новим или ретким облицима - раније романским, сада ромејским, тј. православним: и у псалмима, који су, макар номинално, били практиковани у нашој модерној поезији, и у неосвојеним старим формама као што су кондак, стихира, глоса, светилан, или шире певне структуре попут мале службе, катизме и катавасије.

Основни видик сакралне поезије преузет је у другом делу спева Седмиu $a$, а то значи: поглед у себе и према небесима, али је у томе садржана неизбежна компонента индивидуалног израза и садржаја, без које ове Тешићеве песме не бисмо могли убројати у производ модерне поезије. А оне, по откривачком немиру и дисонанцама, модерне несумњиво јесу, као нпр. у Сйихири на Часно је бити:

Не може пој се зачети лако милост кад блажи / сморене сенке: свака што реч је готово драча, / убод у вену анђела топлог, вече што дражи / крилима крепким; једино може занос певача, / осам кад жица псалмично груне, чедно изрећи, / јошјем док струји девојка стида, оно што плести / језик не уме, оно што Господ таји у врећи: / заранком просут милостив излив утешних вести.

Немоћ људског проговора пред дарованом тајном и овде је смисаони стожер песме, усмерене да слави и призива неовдашњу милост. 
Опит се наставља и у књизи Дар и коб (2006), у области стиховних размера и строфичких форми, али и продубљивање једне дубоко укорењене песничке визије. У средишту пажње тежишних песама ове књиге доспева ритам амфибрашког дванаестерца. Тешић је тиме креативно одговорио на давни изазов постављен мајстором стиха Милана Ракића: „Дванаестерац можете сећи како хоћете, дајући му читав низ тонских и ритмичких вредности, ако имате заједнички делитељ. И нови, ако мисле и осећају, морају наћи оно што одговара њиховој осећајности“ (Ћосић 2002: 140). Поема Калойера Пера, наиме, као и песме Шумор лесковог̄ чесйара или Тарйощи, изведене су у ритму амфибрашког дванаестерца. Стари дванаестерац не препознајемо. Осетимо усталасаност стиха, са по два снажна интонациона удара у оба полустиха. А ритмичку матрицу песник је прво ослушнуо у самом зазиву Калойера Пера, али и у једној ритмичкој фигури српског трохејског дванаестерца, као у примеру из Ракићеве песме Јефимија („Над племеном које обузима тама"). Тешић овај тек ретко, сасвим спорадично оствариван стих, доноси као доследно изведен и захтеван, али и подстицајан ритам.

Песме у збирци Дар и коб чине се за степен музикалније и, такорећи, шумније од претходне поезије истог аутора, али и сугестивне у својој пренаглашеној мелодиозности. Нимало случајно, средином прве деценије овога века, Тешић се обраћа, као приређивач и тумач, поезији Винавера и Настасијевића. У огледу о Настасијевићу, он упућује поглед ка двојици савременика из златног периода српске књижевне авангарде:

Обојица песника, ма колико да се међусобно разликују (а различити су толико да се, на пример, за једну непотписану Настасијевићеву песму не може ни помислити да је Винаверова - и обрнуто), истрајавала су у тежњи за сржном објавом језика, којег су, чистећи га и пречишћавајући, обделавали до тренутка његовог ослобађања у живи духовни трептај самобитан и тајанствен. До религиозности посвећени и привржени језику, они су се мученички упорно савијали на његовим најоштријим кривинама и одржавали над његовим најдубљим провалијама (ТЕшић 2016: 40).

Не морамо бити склони учитавању да овај „саучеснички“ опис претходника разумемо и као Тешићев самоопис. С друге стране, сигнал је упућен, изазов поетичарима и историчарима књижевности: чак и радикализам који показује Милосав Тешић у обнови каталога канонских метара и облика може се довести у блиску везу с конструктивним амбицијама међуратних модерниста, међу којима је Винавер неупитан као писац и гласноговорник, док је Настасијевић тек у новије време задобио убедљиву легитимацију авангардисте по дубини.

Пишући пак о Винаверу, о његовим версификаторским пробама кратког метра, о сугестивној звучности, Тешић као да говори о поетичкој природи песама окупљених у збирци Дар и коб, али, напокон, и о исходима своје целокупне поетике. Полазећи од маркиране синтагме жубор језика из Винаверовог програмског есеја, овако то предочава, сликовито а прецизно: 
Винавер је, кроз треперења помно тражених језичких склопова, доста слутио и наговештавао, доводио је своју шумну мисао у предворје тајне постојања [...] Тај Винаверов пев тече у звучно и кружно ускомешаним језичким сплетовима, некад прозирно ваздушастим, некад толико инверзивним и елиптичним да су се згусли у значењски непрозир - али ce, уз некако блиске дахове неизрецивог, изнад сваке такве његове песме нешто замишљено мрешка и забринуто лебди (ТЕшић 2016: 89).

Винаверовска ㅆyмна мисао - наставимо трагом слика нашег песника тумача - све време лебди понад песама књиге Дар и коб.

Особит мелодијски замах Тешић уткива у основу иницијалне песме низа лирских „шумних руковети“ у књизи Дар и коб. Звучну потку изналази у стиху древног обредног напева, а одатле је, кроз тросложну стопу, потекла по смисаоном опсегу импозантна поема Калоиеера Пера: „Дошумеше творбе са горских весеља.“ Призива исконску обредност стваралачког и чаралачког чина, вилинско коло народног певања. Одатле почиње евокација митског и историјског времена у знаку Женства, од Равијојле виле до толиких надмоћних женских ликова из епске и поглавито мушке повеснице. Калоиеера Пера интегрише сложену и наслојену замисао песникову. А реч је о тежњи за обновом, и матерње мелодије, и свега другог што је у старини било уцело, а данас више није:

Кад йоиустии йажња Бавољем устиројсйву / и дежурној злоби кад

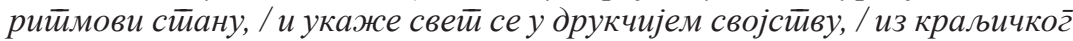
кола виленище бану, / ие тиројичка јуйра и йодневи, щиром, / у навиљке скуйе енерг̄ију бивиу, / од које се - љељо! - иод небеским виром / иреобрази иривид у слова щитоо дищу.

Из утиска који производи ритам амфибрашког дванаестерца изоштрава се слика ткања дата у песми, повезана са нутрином интимног доживљаја света: „те жица ушуми из жуборног чунка, / из разбоја срца, у ткалачко стање.“ Коренски - текст је тканица. Повратити, мелодијском обновом песничког говора, присну прожетост речи и света - један је од уочљивих акцената Тешићевих песама у књизи Дар и коб. Тако у песми Шумор лесковог̄ честиара читамо: „Сједињује све се у шумљење опште.“ Песма настоји да прати такт, звучање и значења природног света, сатканог од звучања. А медијум је силабичко-тонски ритам Тешићевих песама: „куд Језик се хвата и сунцокрет клати, / и држи се смислен, и зри из целине“ (Тарйощ).

Централни део књиге Дар и коб чине руковети сонета са флоралном тематиком и претежним ритмом јампског десетерца, где се до крајњих граница истражује потенцијал једносложних речи (у српском језику необилан), које дају нагласак завршецима стихова. Рестриктивни метрички оквири повлаче собом предоминацију мелодијског начела у обликовању песама, баш онакве винаверовске щиумне мисли. Стога се одвија лексичка десемантизација и семантизација звука и мелодије. Распевани језик приљубљен је 
уз свет који дочарава, или га дискретно сугерише. Тако и Сонет̄ узораних ьива слику обрађене земље дочарава музичким средствима, кроз експресивност рубних једносложница: „Из црних крпа бије земљан мрак / у бистрик дневи, куд се цвркут, гук / каденцом своде вранама у грак, / у чашке биља и у тмуо зук.“ Шта песник постиже том јампском интонацијом лирског десетерца (познатог из Костићевог драмског опуса)? Динамику, скоковитост и ритмичку потенцију, покрет бића које ствара и дах створеног бића. „А заум-шум је у каскади слап“, као да нас изричито у једном сонету упућује са̂м песнички глас. Јампске десетерачке каскаде, и стање предсмисла или заумља, основни су знаци ових звучних песама.

Неретко се језик враћа у свој почетни облик, у шум и шумор, као у јампским осмерачким терцетима Зайевке ирног г̄лог̄a: „Што шумим, шум је то у пад, / низ год у шаш, низ крш у трен / где лето плин је, стрн - и чад.“ Песник и на ову тему, као и на друге битне теме, местимице протне и отворене исказе ауторских намера: „да блеском начне нерв и срж и кост / сажетка суштог, где се чује звон, / почелом зачет: тежак - унисон.“ Поменути ирни гллог жали над својим једносложним оковом и удесом: „О куд ћу, куд ћу тужан шиб, / једнослог кратак, тесан, строг!“, или: „Жуборљив тек сам ткач и чтец.“ На крајњем врху своје презахтевне уметности, као што бива у подвижничким напорима, песнички говор Милосава Тешића враћа и сажима непомућени, трепетни израз почела - упосленом покретачком силом самог језичког звука и ритма.

Тешић је, од својих почетака, посвећени песник фитосфере. Дубља је ту ствар од личног афинитета и од реминисценција на завичајне пределе препуне воћа и трава. Биљна васељена стециште је не само жуђене лепоте него и рађања и обнове којој песнички тежи, као и усклађености са пулсом света. То је простор у који се одбегава из, како је Његош певао, времена земног и судбине људске, окружење што укида историју, а васкрсава митско, „ткалачко стање“. Наспрам „палог времена“ где „историја храмље“, у песми Гром о Светиом Сави затичемо сушти контрапункт: „А живот бучи силом неповрата.“ Готово јединствен је то пример устаничке лирике, где се историјски преокрет самерава с природним препородом, упоредив донекле с Данојлићевом Баладом о йрави, која је „незадржива, од саме себе јача“. Устанак живог света, укупне твари, суделује у српском устанку који песма евокује.

Ако имамо превагу елементарности на уму, онда у пуноћи свога монументалног значења рашчитавамо централне слике песме Шљива срйска. Симбол-воћка постаје овде оно што најдубље јесте, дивна спона земље са сунцем, плод њихове свете свадбе и доказ вечите обнове, „праслика трења земље и звезда“:

Шљивов је видик разгранат, широк, / али и ломан - готов да кљокне. / С њега се човек, Божији прирок, / у надахнућу, отисне, пропне / у озарење: свемир где прска, / сложно где прашти щuлива - а срӣска. 
Завршница песме Шљива срӣска може се стога узети као врхунац подухвата суптилне симболизације: „Дремај, тежино тамјана модрог: / ти си ми гримиз с Тајне рођења, / спомен на софру модрила родног, / чему се враћам из отуђења, / носећи крпе свакојих прња..." Слика повратка и поновног рађања поставља се у смисаони фокус књиге Дар и коб. На другој страни, назиремо назнаке апокалиптичког краја и очекивања, посебно истакнуте у терцетима песме Жеравија (,jер Стаништем коби доцветава време, / зелени се пропаст где жераве бише / и увиру чари у знак без фонеме“) и ронду Има нека васиона (,тек у час ће речен, / кад тела зађу, кад се смори туча, / да пукне зрном, да се разобруча“). Дар почетка и коб краја сустичу се овде и међусобно загледају.

По опробаном и даље развијаном моделу, и у књизи Млинско коло (2010) налази се двадесетоделни циклизовани круг песама, или распарчани спев, насловљен Пащум воденичког̄ бука. Тешић уноси у обухватни песнички простор главнину базичних, у језичко памћење похрањених слика - и оних што су окосница наслојене српске културе и повести и темељ опште књижевне културе, тако и слике из основа личне меморије, која се често ослања на ризницу предања. Воденица је једна од таквих, првотних слика. У поетичком тексту из 1998. године, налазимо сећање на детињство, собом говорљиво:

Ипак, не могу а да још некако не споменем воденицу, чије ме брујање кроз брашнене праменове прати од детињства, јер су и моји преци били воденичари у некад чувеној, а сада закоровљеној, Тещића воденици, у којој се прашњаво белео и квасио до костију мој деда Драгољуб, па се почесто и зеленео, обрастао у трину која му је од мокрине проклијавала из гуња. (А знао је испећи као памук меку погачу, ону што под прстима дише, ону што се ни с једним другим јелом не једе, јер би је свако покварило) (Тешић 1998: 278-279).

Али, без обзира на откривену интимну вредност воденичког мотива, Тешић није од песника што се препушта лепљивој сладости носталгије, нити пресном посредовању фолклорних садржаја које искуствено носи. Традицијске садржаје, као и личне, песник и овог пута подвргава стилизацији и помном преобликовању. У детињу свест урезана воденица, значењски прочишћена и обремењена, тако узраста до космичког симбола, који није могуће сагледати, јер се указује као активни праобразац свега што постоји и што је постојало. Ма колико у праоснови ове лирске творевине била слика закоровљене Тещића воденице, над њоме се саздало многозначно здање, које своју поузданост, ипак, дугује и своме конкретном полазишту.

Тај симбол воденичког точка, кола, витла, од песме до песме у циклусу/спеву Пащумм воденичког̄ бука, асоцијативно се шири и грана на све четири стране и активира толике наслеђене смисаоне нити, плетући од њих густу и јаку мрежу. И наслов циклуса упућује да је реч о исказу што представља одјек изворне стварности воденичког микрокосмоса одавно пресељеног у непостојање. Не звуци него йазвуйи, сачувани у сећању на једну од 
најважнијих установа за обезбеђење живота у патријархалној заједници. У лирици се од звука одувек почиње, али се, код Тешића, у звучној димензији стиче и извор и увор читавог песничког чина.

Али, између извора и увора језик опосли и пробуди, сугерише и повеже оно што може учинити у пуној акцији и кондензованом виду. Измирује супротности и спаја неупоредиве размере, као у стиху песме Клокоч-йойок: „може свемир да се скапи / у ширину једне капи.“ Поменута, уводна осмерачка песма у четири дела сва је у таквим немогућим, разрешујућим спојевима. Тај нестали Клокоч-йойок који, по речима песме „није себи мера“, коме је ушће уједно и извор, постаје несводљиви знак шумног, хучног, гргољавог, кружног неизрека, егзистенцијалног и песничког подједнако: „Текао је куд је хтео / Узводно је воду прео.“ У разлагању на основно, посредством воденице као полазне слике, Тешић усмерава тежиште на елемент воде. Она је извор свега постојећег, тајна међа светова, али и ток (и то кружни) што протиче између земље и небеса. У продору до почела, појављују се фигуре из античких митова о постању света, од праоца Океана до митске прареке Ахелоја и граничног Стикса којим жедне сени броде ка другој обали, до библијских ликова и библијских река, од рајских до оних из свете земље.

Као што је у књизи Куйиново звук топонимске бројанице српских земаља био иницијална тачка за лирско имагинирање, тако је и овде сложени звучни ансамбл мељаве, од разних акустичких варијација воденог протока кроз сложени уређај млина, до бука воде што се силовито сручује са точка и омаје што прска около, стални чинилац који асоцијативно наводи ту воду на драматику и мистику последњих и првих питања. Песник је, подсећамо, у поетичком тексту у којем помиње Тешића воденицу унео и воденички речник, чиме је лексикографски, штавише енциклопедијски, подложио свој космолошки поглед на ову древну корисну направу. Тај космолошки склоп, и вербалне фикције које песник разгранава, држе се на прецизном, зналачком опису делова и делића воденичког механизма и сваки од корака у томе процесу поприма симболичку вредност, односно постаје карика у сугерисаној реалности вишег и највишег реда. А та реалност у својој бити је двострука, себи сушто противречна, у млинском колу стварања и разарања. Млин с небеса, у изводној песми тог наслова, за песника: „он је тутањ несмирења / у систему несистема“, али последња реч овога круга ипак бива следећа, недоречена али светло, јеванђељски потцртана: „Који меље воду живу / познаје се по мељиву.“

Ненаметљиво, али уочљиво, у моту једног ронда о воденичишту или млиништу, значи о простору где воденице више нема, упослен је цитат из

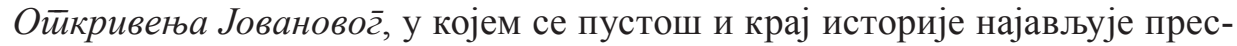
танком хуке „камена воденичнога“. О таквом одсуству Тешић овде и пева, физичком и метафизичком, дајући пашум уместо шума. Колико год је, рецимо у песмама књиге Дар и коб, песнички рекреирао ритам почела толико су апокалиптичке слике саме навирале у поенте тих песама и давале им кључне смисаоне нагласке. У елегичној слици нестанка протиче и дужа 
песма Жички наййис, у чијем елегичном опису преваже слика онога што је било и нестало, унутарња дакле представа, у односу на оно што се види у наше доба, када „у ништење грезну чистота и понос“ и „кад логика нуле лепоту изврста“. Сенка нестанка надвила се и над споменик страдања и опстанка какав је Жича и на саму идеју Жиче. С друге стране, циклус Белег̃ Сйеванов писан је у знаку обраћања траговима породичних почетака. Тај белег, остатак гроба првог знаног претка стоји на почетку седмоделне песме на чијем је крају ведри призор општег ускрса у дан Страшног Суда:

Са раскршћа смисла идеје су стукле, / па дозрео час је да све узлепрша: // те разгази ноћ се, уз жагор што чини / да коракне Стеван, да крену се ини / са гробаља селских док жижи имела - / а пристижу силни из свакојег села.

Верујући прилив есхатолошког оптимизма Тешић оставља за финале, смешта у епилошку песму Пустищъ $а, y$ Поћуш $u$, где „ведрина се светли у

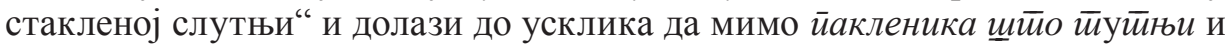
йрајањ ваведењ $а$ у неки други простор, јамачно у Нови Јерусалим, град подигнут од свеколиких високих и сјајних човечанских надања. Ако је Сйоредно небо (1968) у критици препознато као зенит Попиног песничког подухвата, јер симболички оваплоћује најапстрактније односе видљивог и невидљивог постојања, онда је Тешић циклусом о млинском колу, једном од најприснијих и уједно енигматичних слика детињства, опредметио живу слику васељенског кружног тока. Уместо воденице, чини се да се окреће васиона.

Разнострана и слојевита знања и значења активира поезија Милосава Тешића. Поезија, која је и самим наслојеним језиком отежана, ризикује да бројна важна културна обавештења остану незапажена. Свестан тога ризика, а без склоности да мистификује ерудитну подлогу, песник најпре књигу Млинско коло снабдева „глосаром“, у којем појашњава лексичка и предањска значења кључних речи. Тешићев глосар директно дозначује шта је положено у његове песничке текстове, шта чини темељне семантичке слојеве и односе. Истоврсним додатком песник накнадно опрема допуњена издања спева Седмица (2015) и поеме Калойера Пера (2018). Елиотове напомене уз Пустиу земљу, као узор за овакав ауторски гест, више дискретно упућују на изворе него што објашњавају. Тешић, српски лексикограф, излази у сусрет посвећеним читаоцима да - како је писало на косовском мраморном стубу покрај неких речи не промину и не превиде их „као нешто залудно и ништавно“. Песник раскрива моћан културни подтекст, насложен у његову поезиjу, која и својим звучним ткањем заокупља пажњу. „За једнога књижевника најзанимљивије је читати речнике“, изрече у напред навођеном, познатом разговору Милан Ракић (Ћосић 2002: 143) - а читаоцу је свакако од користи. Јер и тако, наочиглед, распознаје шта све учествује у градњи поетског хоризонта, потврђујући и Лотманове речи да је уметност „најекономичнији и 
најкомпактнији начин чувања и преношења информације“(Лотман 1976: 56), информације коју прихватамо нашим и умним и чулно-осећајним сензорима.

Милосав Тешић је одавно препознат као песник енциклопедијске, лексикографске парадигме, поезије што тежи за свеобухватним опсегом обавештења и заснива се на искуству дуговеког језика којег обделава. Језички пресек Тешићев уједно чини пресек слојева културе којој српски језик представља медијум и скривницу. Ако је песник културе, а свакако јесте, онда је Тешић песник националне културе. Песник културе у дубину, а не у летимичну ширину. И песничка претходница, наслеђе, раскрива се у таквом пресеку као слика непрекидног дијалога између сродничких гласова у „млинском колу“ постојања и општења.

Песницима не треба надевати једнозначне ознаке, јер, ако су прави и остварени, оспориће их с неочекиваних страна. Отуда може бити парадоксално да се конзервативац и класичар покаже несмиренији истраживач од разних подгрејаних авангардиста, као и неконвенционалнији поред свих могућих погодби до којих држи. Шта је учинак сталног, беспоштедног опитовања песника Милосава Тешића? Обновљен и приновљен метрички репертоар (насупрот предвидљивости и статици), импресиван лексички фонд изведен из пасиве и понегде песнички новосаткан, језик разгранат и разигран по дијахронији и савремености, размахана али контролисана поетска имагинација, маркантни културни симболи оделотворени у остварењима од кратких до дужих обима. У жижи свих напора и местимичних подвига Милосава Тешића лежи посвећеност ресурсима језика и облика. При таквом приступу пространству речи и ограничењима у њиховом коришћењу садржана су нека од најсмелијих знаних искустава, од симболистичких до авангардних, али и рефлекси савремених изазова на које песник реагује.

\section{ИЗВОРИ И ЦИТИРАНА ЛИТЕРАТУРА}

Аверинцев, Сергеј, Ритам као теодицеја. Срӣски југ̄ 3/ 4, јесен 2010.

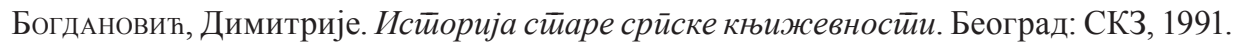

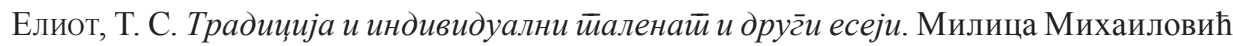
(прев.). Београд: Службени гласник, 2017.

ЈАкобсон, Роман. Линг̄висӣика и йоеӣика. Београд: Нолит, 1966.

Колен, Леон. Јакобсон. Поеӣика и метирика. Београд: Народна књига - Алфа, 1998. КоЈен, Леон. Оглледи о йоезији. Београд: Чигоја, 2012.

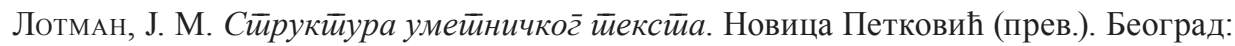
Нолит, 1976.

Микић, Радивоје. Милосав Тешић као симболиста. Милосав Тещuћ, йесник. Краљево: Народна библиотека, 1998.

МилАновић, Александар. Фолклорно и архаично у језичкој структури песама Милосава Тешића. Милосав Тещић, иеесник. Краљево: Народна библиотека, 1998. 
МилАновић, Александар. Лексичке карактеристике у Тешићевим збиркама Дар и коб и Вейрово йоље. Звук, мет̄ар и смисао у йоезији Милосава Тещића. Зборник радова. Београд - Требиње: Институт за књижевност и уметност, 2016.

Миљковић, Бранко. Есеји и крит̄ике. Сабрана дела. Ниш: Нишки културни центар, 2018.

ПАвловић, Миодраг. Осам иесника. Београд: Просвета, 1964.

Петковић, Новица. О̄лледи из срӣске йоеӣике, Београд: Завод за уџбенике, 2006.

Петковић, Новица. Поезија у ог̄ледалу крийике. Нови Сад: Матица српска, 2007.

РАдуловић, Марко М. Стварање као похвала: поетска религиозност у Седмици Милосава Тешића. Звук, метиар и смисао у иоозији Милосава Тещића. Зборник радова. Београд - Требиње: Институт за књижевност и уметност, 2016.

Самарџија, Снежана. Усред куће видим зову. Милосав Тещић, иесник. Краљево: Народна библиотека, 1998.

Стипчевић, Никша. Песма укрштених путева. Милосав Тещић, иесник. Краљево: Народна библиотека, 1998.

ТЕшић, Милосав. Камен угаони у сазвежђу кукурека. Милосав Тещић, иеесник. Краљево: Народна библиотека, 1998.

ТЕшић, Милосав. Есеји и сличне радње. Београд: Завод за уџбенике и наставна средства, 2004.

ТЕшић, Милосав. Певање и мера. Београд: Службени гласник, 2016.

ТЕшић, Милосав, Александар Јовановић. Као да нешто драгоцено држим на окупу. Звук, мет̄ар и смисао у йоезији Милосава Тещића. Зборник радова. Београд Требиње: Институт за књижевност и уметност, 2016а.

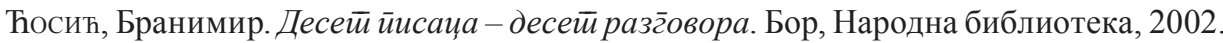
Фридрих, Хуго. Сӣрукӣура модерне лирике. Томислав Бекић (прев.). Нови Сад: Светови, 2003.

Христић, Јован. Поезија и криӣика йоезије. Нови Сад: Матица српска, 1957.

Dragan L. Hamović

\section{RECANONIZATION OF VERSE AND FORM AND ITS MEANING IN THE POETRY OF MILOSAV TEŠIĆ}

\section{Sum mary}

The paper attempts to provide a comprehensive view of the poetic work of Milosav Tešić starting with the poetic justification of his consistent choice to sing in a metrically organized verse, which requires many metric innovations as well as singing in constant stanza forms. We analyze the developmental path of Tešić's poetic opus, which has been marked with thematic shifts and extensions, in the light of a developed poetic and cultural awareness. Milosav Tešić has long been recognized as a poet of the encyclopaedic or 
lexicographic paradigm. Tešićs linguistic intersection is simultaneously an intersection of cultures, whose language is the medium of national culture as a space of the wide and widest cultural space. Poetic heritage is also discovered in that intersection as an image of continuous dialogue between similar voices in the mill of existence and encounters. What is the effect of this constant research? A renewed and restored metric repertoire (as opposed to predictability and static), an impressive lexical fund deduced from the passive with occasional poetic neologisms, a language branched out and playful diachronically and contemporarily, an unusual but controlled poetic imagination and impressive cultural symbols embodied both in very short and very long forms. Milosav Tešić is a supreme author who synthesizes many constructive efforts of the dynamic past century in Serbian poetry.

Институт за књижевност и уметност

Београд

hamovicdragan@gmail.com 